\title{
Foreword
}

\section{Fertility in dairy cows: bridging the gaps}

\author{
M. D. Royal' ${ }^{1}$ R. F. Smith ${ }^{1}$ and N. C. Friggens ${ }^{2}$ \\ ${ }^{1}$ Department of Veterinary Clinical Sciences, University of Liverpool, Leahurst, Neston, South Wirral CH64 7TE, UK; ${ }^{2}$ Faculty of Agricultural Sciences, University of \\ Aarhus, Aarhus, Denmark
}

Dairy cattle are an integral part of agriculture worldwide, providing many products in addition to milk for the human population. The efficient production of these products is of utmost importance and high reproductive performance is absolutely crucial to this. In September 1999, Dr Michael Diskin led a committee (Dr Joseph M. Sreenan, Prof James Roche, Prof Maurice Boland and Dr Diarmuid O'Callaghan) to organize an extremely successful and informative occasional meeting 'Fertility in the High-Producing Dairy Cow', jointly with the British Society of Animal Science (BSAS) in Galway, Ireland, to address the important issue of declining reproductive performance in dairy cattle. The full papers were later published in an occasional publication by BSAS (2001). As discussed by Dr John Robinson in the conference summary, ' ... delegates, after a starting point of uncertainty about how to deal with the problem [infertility], came away very well informed scientifically and, if perhaps with varying views as to the best way forward, more aware of the multidisciplinary research and development approach now being used to investigate it'. Dr Robinson concluded his summary by stating 'Reversing this relentless decline in dairy cow fertility, while simultaneously sustaining high yields, is not going to be easy...... it is a challenge that will require great interchange of information and ideas between science, practice, research and development. The establishment of contacts and beginning of such interchange has been initiated during this [Galway, 1999] meeting and it is essential that this is sustained.'

Now, exactly 8 years later, it seemed time for those representatives from all disciplines involved in attempting to improve dairy cattle fertility to reconvene. Since 1999, the continued and well-documented decline in dairy cow fertility worldwide (Royal et al., 2000; Lucy, 2001; Mayne et al., 2002; Washburn et al., 2002; Lopez-Gatius, 2003; Swedish Dairy Association, 2005) has prompted new research into diverse aspects of dairy cow reproduction. To name but a few areas and publications, these include aspects such as genetics (Royal et al., 2002a and 2002b; Berry et al., 2003; Haile-Mariam et al., 2003; Philipsson and
Lindhe, 2003; Wall et al., 2003; Holmberg and AnderssonEklund, 2006; Weigel, 2006; Hayhurst et al., 2007; Petersson et al., 2007; Veerkamp and Beerda, 2007), nutrition (Kadokawa and Martin, 2006; Robinson et al., 2006; Chagas et al., 2007; Friggens and Newbold, 2007; Wathes et al., 2007) Economics (Vargas et al., 2002; Esslemont, 2003; Santarossa et al., 2004; McGuirk et al., 2007), veterinary interventions and management (Refsdal, 2000; Roche et al., 2000; Sheldon et al., 2004; Bertoni et al., 2006; Diskin et al., 2006; Drillich et al., 2006; Mansell et al., 2006; Mee, 2007; Valergakis et al., 2007). It has also prompted the development of new technology and applications in the field. The purpose of this conference and subsequent publications is to provide an update on these activities since 1999 and to provide a forum for 'bridging the gaps' between the different disciplines involved.

Invited and submitted theatre and poster sessions included new, up and coming presenters in addition to keynote speakers from across the globe, recognized as international experts in their field. As was the case at the 1999 meeting, the content is of direct interest to scientists, university lecturers, veterinarians, farm advisors and technical representatives working within the dairy industry as well as many dairy farmers. The following papers are a collection of research published at the conference.

Dobson et al. (2008) highlight the factors predisposing to lowered fertility and disrupted oestrus in order to review 'Why it is getting more difficult to successfully Al dairy cows'. The review by Morris and Diskin (2008), considers the current knowledge on embryo growth, development and survival in the cow and how these may be influenced by changes in uterine function and the concentration of systemic progesterone. Leroy et al. (2008), continues the investigations into the embryo reviewing a number of possible mechanisms linking negative energy balance to oocyte quality. Furthermore, in the event an embryo is formed after fertilization, the paper investigates whether the quality of early life is impaired. Interestingly, the prenatal environment is known to have a large impact not only 
Royal, Smith and Friggens

on foetal development but also health in later life and since its identification in 1986, the developmental origins of adult disease, has been applied to many areas of science. The paper by Gardner et al. (2008) reviews specifically for the first time 'Developmental programming of reproduction and fertility in farm animals'.

The average dairy cow survives only three lactations. This severely limits opportunities for on-farm selection of breeding cows in addition to presenting a welfare issue and causing economic loss. Wathes et al. (2008) review a range of factors influencing heifer survival and fertility on commercial dairy farms. In their paper titled 'Integration of physiological mechanisms that influence fertility in dairy cows', Garnsworthy et al. (2008) review the potential modulating role of additional factors, such as peripheral metabolites, metabolic hormones and locally produced growth factors suggesting that progress towards restoring fertility could be made by an integrated approach that allows for interactions between physiological mechanisms that regulate metabolism and reproduction. Following parturition, contamination of the uterine lumen by bacteria is ubiquitous, and uterine health is impaired in cattle because infection persists. In their paper, Williams et al. (2008) discuss the numerous mechanisms underlying uterine disease in cattle from the whole animal to the cell. Finally, developing new research areas in the field of functional genomics, such as epigenetics, RNA interference, variable copy numbers and nutrigenomics, are discussed in the review by Beerda et al. (2008), including their promising future value for dairy cow fertility.

The meeting promoted one of the major aims of the BSAS, which is to encourage fruitful exchange of information and ideas between all of those involved in the science and practice of animal production.

The organizers are very grateful for the sponsorship from BASF, Genesis Faraday, Genus ABS, Holstein UK and CIS, Merial, Pfizer, Reproduction Specialities Inc., The Stapledon Memorial Trust and World Wide Sires Ltd. We would also like to thank everyone who has contributed to bringing this excellent international conference to fruition.

\section{References}

Beerda B, Wyszynska-Koko J, te Pas MFW, de Wit AAC and Veerkamp RF 2008. Expression profiles of genes regulating dairy cow fertility: recent findings, ongoing activities and future possibilities. Animal 2, 1158-1167.

Berry DP, Buckley F, Dillon P, Evans RD, Rath M and Veerkamp RF 2003. Genetic parameters for body condition score, body weight, milk yield, and fertility estimated using random regression models. Journal of Dairy Science 86, 3704-3717.

Bertoni G, Trevisi E, Han X and Bionaz M 2006. The relationship between inflammatory condition and liver activity in the puerperium and their consequences on fertility in dairy cows. Journal of Animal Science 84(suppl. 2), 84.

British Society of Animal Science (BSAS) 2001. Fertility in the high producing dairy cow. BSAS Occasional Publication no. 26. BSAS, Edinburgh, Scotland.

Chagas LM, Bass JJ, Blache D, Burke CR, Kay JK, Lindsay DR, Lucy MC, Martin GB, Meier S, Rhodes FM, Roche JR, Thatcher WW and Webb R 2007. New perspectives on the roles of nutrition and metabolic priorities in the subfertility of high-producing dairy cows. Journal of Dairy Science 90, 4022-4032.
Diskin MG, Murphy JJ and Sreenan JM 2006. Embryo survival in dairy cows managed under pastoral conditions. Animal Reproduction Science 96, 297-311.

Dobson H, Walker SL, Morris MJ, Routly JE and Smith RF 2008. Why is it getting more difficult to successfully artificially inseminate dairy cows? Animal 2, 1104-1111.

Drillich M, Mahlstedt M, Reichert U, Tenhagen BA and Heuwieser W 2006. Strategies to improve the therapy of retained fetal membranes in dairy cows. Journal of Dairy Science 89, 627-635.

Esslemont RJ 2003. The costs of poor fertility and what to do about reducing them. Cattle Practice 11, 237-250.

Friggens NC and Newbold JR 2007. Towards a biological basis for predicting nutrient partitioning: the dairy cow as an example. Animal 1, 87-97.

Gardner DS, Lea RG and Sinclair KD 2008. Developmental programming of reproduction and fertility: What is the evidence? Animal 2, 1128-1134.

Garnsworthy PC, Sinclair KD and Webb R 2008. Integration of physiological mechanisms that influence fertility in dairy cows. Animal 2, 1144-1152.

Haile-Mariam M, Morton JM and Goddard ME 2003. Estimates of genetic parameters for fertility traits of Australian Holstein-Friesian cattle. Animal Science 76, 35-42.

Hayhurst C, Sørensen MK, Royal MD and Løvendahl P 2007. Metabolic regulation in Danish bull calves and the relationship to the fertility of their female offspring. Journal of Dairy Science 90, 3909-3916.

Holmberg $\mathrm{M}$ and Andersson-Eklund L 2006. Quantitative trait loci affecting fertility and calving traits in Swedish dairy cattle. Journal of Dairy Science 89, 3664-3671.

Kadokawa $\mathrm{H}$ and Martin GB 2006. A new perspective on management of reproduction in dairy cows: the need for detailed metabolic information, an improved selection index and extended lactation. Journal of Reproduction and Development 52, 161-168.

Leroy JLMR, Van Soom A, Opsomer G and Bols PEJ 2008. The consequences of metabolic changes in high yielding dairy cows on oocyte and embryo quality. Animal 2, 1120-1127.

Lopez-Gatius $F$ 2003. Is fertility declining in dairy cattle? A retrospective study in northeastern Spain. Theriogenology 60, 89-99.

Lucy MC 2001. Reproductive loses in high producing dairy cattle: where will it end? Journal of Dairy Science 84, 1277-1293.

Mansell PD, Cameron AR, Taylor DP and Malmo J 2006. Induction of parturition in dairy cattle and its effects on health and subsequent lactation and reproductive performance. Australian Veterinary Journal 84, 312-316.

Mayne CS, McCoy MA, Lennox SD, Mackey DR, Verner M, Catney DC, McCaughey WJ, Wylie ARG, Kennedy BW and Gordon FJ 2002. Fertility of dairy cows in Northern Ireland. Veterinary Record 150, 707-713.

McGuirk BJ, Forsyth R and Dobson H 2007. Economical cost of difficult calvings in the UK dairy herd. Veterinary Record 161, 685-687.

Mee JF 2007. The role of the veterinarian in bovine fertility management on modern dairy farms. Theriogenology 68(suppl. 1), S257-\$265.

Morris D and Diskin M 2008. Effect of progesterone on embryo survival. Animal 2, 1112-1119.

Petersson KJ, Berglund B, Strandberg E, Gustafsson H, Flint APF, Woolliams JA and Royal MD 2007. Genetic analysis of luteal activity measures postpartum in dairy cows. Journal of Dairy Science 90, 427-434.

Philipsson J and Lindhe B 2003. Experiences of including reproduction and health traits in Scandinavian dairy cattle breeding programmes. Livestock Production Science 83, 99-112.

Refsdal AO 2000. To treat or not to treat: a proper use of hormones and antibiotics. Animal Reproduction Science 60-61, 109-119.

Robinson JJ, Ashworth CJ, Rooke JA, Mitchell LM and McEvoy TG 2006. Nutrition and fertility in ruminant livestock. Animal Feed Science and Technology 126, 259-276.

Roche JF, Mackey D and Diskin MD 2000. Reproductive management of postpartum cows. Animal Reproductive Science 60-61, 703-712.

Royal MD, Darwash AO, Flint APF, Webb R, Woolliams JA and Lamming GE 2000. Declining fertility in dairy cattle: changes in endocrine and traditional measures of fertility. Animal Science 70, 487-501.

Royal MD, Flint AP and Woolliams JA 2002a. Genetic and phenotypic relationships among endocrine and traditional fertility traits and 
production traits in Holstein-Friesian dairy cows. Journal of Dairy Science 85 958-967.

Royal MD, Pryce JE, Woolliams JA and Flint AP 2002b. The genetic relationship between commencement of luteal activity and calving interval, body condition score, production, and linear type traits in Holstein-Friesian dairy cattle. Journal of Dairy Science 85, 3071-3080.

Santarossa JM, Stott AW, Woolliams JA, Brotherstone S, Wall E and Coffey MP 2004. An economic evaluation of long-term sustainability in the dairy sector. Animal Science 79, 315-325.

Sheldon IM, Noakes DE, Rycroft AN and Dobson H 2004. Effect of intrauterine administration of oestradiol on postpartum uterine bacterial infection in cattle. Animal Reproduction Science 81, 13-23.

Swedish Dairy Association, 2005. Husdjursstatistik (Cattle Statistics) 2005. Svensk Mjölk, Box 1146, 63180 Eskilstuna, Sweden.

Valergakis GE, Arsenos G and Banos G 2007. Comparison of artificial insemination and natural service cost effectiveness in dairy cattle. Animal 1, 293-300.

Vargas B, Groen AF, Herrero M and Van Arendonk JAM 2002. Economic values for production and functional traits in Holstein cattle of Costa Rica. Livestock Production Science $75,101-116$.
Veerkamp RF and Beerda B 2007. Genetics and genomics to improve fertility in high producing dairy cows. Theriogenology 68 , S266-\$273.

Wall E, Brotherstone S, Woolliams JA, Banos G and Coffey MP 2003. Genetic evaluation of fertility using direct and correlated traits. Journal of Dairy Science 86, 4093-4102.

Washburn SP, Silvia WJ, Brown CH, McDaniel BT and McAllister AJ 2002. Trends in reproductive performance in southeastern Holstein and Jersey DHI herds. Journal of Dairy Science 85, 244-251.

Wathes DC, Bourne N, Cheng Z, Mann GE, Taylor VJ and Coffey MP 2007. Multiple correlation analyses of metabolic and endocrine profiles with fertility in primiparous and multiparous cows. Journal of Dairy Science 90 , 1310-1325.

Wathes DC, Brickell JS, Bourne NE, Swalia A and Cheng Z 2008. Factors influencing heifer survival and fertility on commercial dairy farms. Animal 2 1135-1143.

Weigel KA 2006. Prospects for improving reproductive performance through genetic selection. Animal Reproduction Science 96, 323-330.

Williams EJ, Herath S, England GCW, Dobson H, Bryant CE and Sheldon IM 2008. Effect of Escherichia coli infection of the bovine uterus from the whole animal to the cell. Animal 2, 1153-1157. 